\title{
Population Briefs, Vol. 14, no. 1
}

Population Council

Follow this and additional works at: https://knowledgecommons.popcouncil.org/ series_newsletters_popbriefs How does access to this work benefit you? Let us know!

\section{Recommended Citation}

Population Briefs 14(1): New York: Population Council, 2008. 


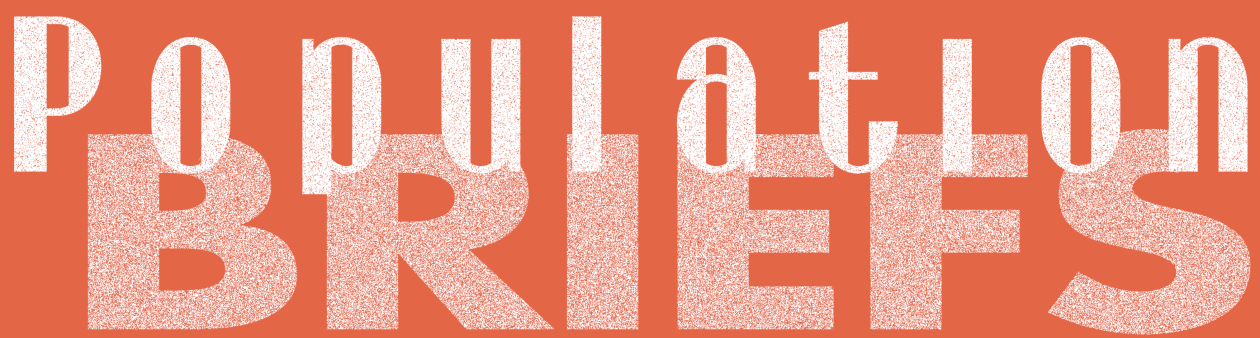

Reports on Population Council Research

August 2008 Volume 14, Number 1

The Mirena ${ }^{\circledast}$ intrauterine system is a highly effective and safe contraceptive; it also provides additional health benefits.

See story, page 2.

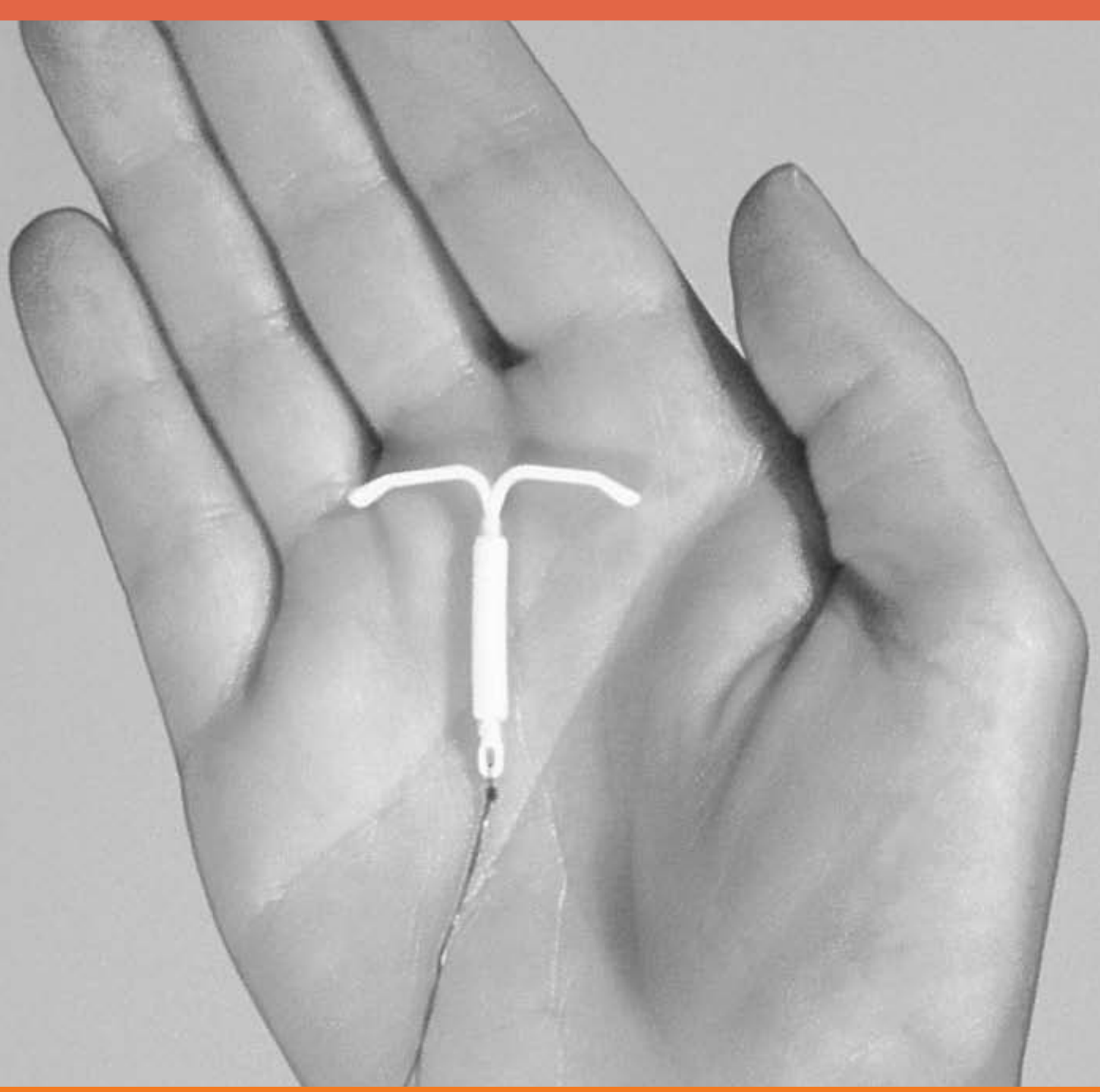




\section{IUDs: A Beneficial, Underused Contraceptive Technology}

"Despite the many benefits of intrauterine contraception, this method is underused in most countries of the world, with the notable exception of China," says eminent obstetriciangynecologist Daniel R. Mishell Jr. A long-time member of the Population Council's International Committee for Contraception Research, Mishell is also editor-in-chief of the journal Contraception and a professor of obstetrics and gynecology at the Keck School of Medicine, University of Southern California. He co-authored a January 2008 article contending that intrauterine contraception, commonly called IUDs (for intrauterine devices), should be promoted by doctors as an alternative to tubal ligation. Also known as "tying the tubes," tubal ligation is surgery to close a woman's fallopian tubes, which connect the ovaries to the uterus.

Tubal ligation is the second most popular form of contraception in the United States, coming in a close second to the birth control pill. Among women in the United States who practice contraception, 27 percent have had their tubes tied and 30 percent take the Pill. Only 2 percent use an IUD.

Mishell points out that IUDs compare very well to tubal ligation. The two approaches offer excellent protection against pregnancy, with IUDs being somewhat more effective than some types of tubal ligation. An IUD can be inserted in a doctor's office quickly, easily, and with little pain. Tubal ligation is a surgical procedure that must be performed in an operating room and may have a painful recovery period. IUDs are easily removed in the doctor's office, and fertility is restored. Studies in different cultures have shown that some women who have had their tubes tied later regret it. In one study, more than 11,000 women in the United States who had been sterilized were interviewed within 14 years after the fact. Twenty percent of those who had had their tubes tied before age 30 expressed regret.
But reversing a tubal ligation is a complicated and often unsuccessful surgical procedure. Both IUDs and tubal ligation offer some protection against cancer: IUDs protect against endometrial cancer, and tubal ligation protects against ovarian cancer.

\section{An international meeting on IUDs}

A recent issue of Mishell's journal Contraception focused entirely on the Fifth International Symposium on Intrauterine Devices and Systems for Women's Health,

\section{An IUD can be}

inserted in a doctor's

office quickly, easily,

and with little pain.

publishing all the presentations made at the meeting. (The issue has been translated into Spanish by the Instituto Chileno de Medicina Reproductiva.) The symposium was organized by experts on contraception, under the auspices of the Population Council and the United Nations Population Fund. "This symposium provides the most recent information in this field and offers recommendations about the appropriate indications and safe conditions for the use of intrauterine contraception," wrote Régine Sitruk-Ware and Peter Donaldson in the introduction to the special issue. SitrukWare is the Population Council's executive director of reproductive health research and development. Donaldson is the president of the Population Council.

\section{Types of IUDs}

Two kinds of IUDs are available today: copperbearing and progestin-releasing. The most common copper-bearing IUD is the Paragard ${ }^{\circledast}$ Copper T 380A. Paragard has been used by millions of women around the world. The only progestin-releasing IUD now available is Mirena ${ }^{\circledast}$. It is called an intrauterine system as it delivers a low dose of the progestin levonorgestrel in the uterus. Both Paragard and Mirena were developed and tested by the Population Council and its International Committee for Contraception Research. They are extremely effective and last for years.

An enduring myth about IUDs is that IUD insertion frequently pushes bacteria into the uterus, where it can develop into pelvic inflammatory disease (PID), a serious illness. Scientists at the symposium presented research refuting this belief. Olav Meirik, of the Instituto Chileno de Medicina Reproductiva, reviewed past studies on the link between IUDs and PID. He found that there is a slight risk of PID in the first month after IUD insertion. Women who develop PID after IUD insertion likely had an undiagnosed infection of the cervix (the lower part of the uterus) at the time of insertion. But, after the first month the incidence of PID is low among IUD users, similar to the rate in the general public. Meirik found that in the past, researchers did not take into account several biases that exaggerated the link between PID and IUDs. For example, many studies allowed women in control groups to use contraceptive methods that lowered their risk of PID. Additionally, IUD use has become safer in recent decades as doctors have been using a more effective screening and counseling process.

Another myth is that IUDs are an inappropriate contraceptive for women who have not given birth. Researchers at the symposium discussed the use of both copperbearing and progestin-releasing IUDs by such 
women. David Hubacher, of Family Health International, reviewed published studies on copper IUDs; Sarah Prager and Philip D. Darney, of San Francisco General Hospital, reviewed available literature about Mirena. The researchers found that all available IUDs are safe and extremely effective for women who have never given birth. There is some evidence that women who have never given birth may be slightly more likely than women who have given birth to expel copper IUDs. This may be due to the size and shape of current copper IUDs. The researchers suggest that to address this problem small changes may be needed in the design of these devices.

\section{How IUDs work}

Over the years, questions have arisen about how IUDs work. Some people believe that because IUDs are placed in the uterus, they usually work by preventing fertilized eggs from implanting there. However, a review by María Elena Ortiz and Horacio B. Croxatto, of the Instituto Chileno de Medicina Reproductiva, showed that this belief is not supported by the available evidence. (Croxatto is a member of the Population Council's International Committee for Contraception Research.) IUDs induce a local inflammatory reaction in the uterus. Substances released by the IUD itself, or by this inflammatory reaction, prevent pregnancy. But, in general, is pregnancy prevented before or after fertilization?

In one group of studies, doctors looked for sperm in the fallopian tubes (where fertilization takes place). In IUD users they found few or no sperm, but in women who were not using IUDs they did find sperm. Another group of studies looked at early embryonic loss. Fertilization followed by early embryonic loss is a common occurrence in young, sexually active women who are not using contraception. If IUDs were preventing embryonic implantation, early embryonic loss would be more common in women using IUDs than among women who were not using contraception. But studies have shown that it is actually much less common in women using IUDs. The research suggests that the substances released by the IUD, or by the inflammatory reaction it causes, damage sperm and eggs and prevent them from forming viable embryos. Thus, the usual mechanism by which IUDs prevent pregnancy is by preventing fertilization.

A number of researchers at the symposium reviewed knowledge about the cancer-preventing effects of IUDs. Kathryn M. Curtis, of the U.S. Centers for Disease Control and Prevention, and Polly A. Marchbanks and Herbert B. Peterson, from the University of North Carolina at Chapel Hill, found no evidence of increased risk of any kind of cancer with IUD use. In fact, nearly all studies found a significantly reduced risk of endometrial cancer among women using IUDs.

\section{The intrauterine}

delivery of progestin

"has opened new

vistas in gynecological

therapy."

A reduction in cancer risk is only one of the non-contraceptive health benefits of the IUD. The symposium featured a dozen presentations on additional health benefits of Mirena, the levonorgestrel-releasing intrauterine system. The device is valuable as a nonsurgical treatment for excessive menstrual bleeding related to a number of medical conditions and for pelvic pain related to endometriosis and adenomyosis. Excessive menstrual bleeding can lead to anemia and may require surgery, including hysterectomy.

\section{Additional bealth benefits of Mirena}

Numerous studies have shown that when women with excessive menstrual bleeding are treated with Mirena, a significant percentage of them can avoid a hysterectomy. Ian Milsom, of Sweden's Goteborg University and Sahlgrenska University Hospital, reviewed the available studies. In one randomized controlled trial, Mirena was compared to hysterectomy. Only 42 percent of women who received Mirena subsequently underwent a hysterectomy during the five-year study period. The total cost of health care related to the excessive menstrual bleeding was 40 percent lower among women who stayed with Mirena than with those who got a hysterectomy. In another study, women who were considering a hysterectomy to treat their excessive menstrual bleeding were randomized either to continue their current medical treatment or to receive Mirena. At six months, 64 percent of the women who got Mirena decided they did not want a hysterectomy. Only 14 percent of the women receiving typical medical treatment decided not to get a hysterectomy.

Ian S. Fraser, of the University of Sydney and a member of the Population Council's International Committee for Contraception Research, reported that, "Reasonable evidence exists that intrauterine levonorgestrel helps to prevent the development of uterine fibroids, endometriosis, endometrial hyperplasia (a potentially precancerous condition), acute pelvic inflammatory disease, and a wide range of menstrual symptoms. There is also promise of prevention of endometrial carcinoma, endometrial polyps, infertility, and perhaps adenomyosis." David A. Grimes, from Family Health International, told the group that the intrauterine delivery of progestin "has opened new vistas in gynecological therapy."

\footnotetext{
SOURCES

Grimes, David A. and Daniel R. Mishell Jr. 2008

"Intrauterine contraception as an alternative to interval tubal sterilization," Contraception 77(1): 6-9

Quinto Simposio Internacional sobre Dispositivos y Sistemas Intrauterinos para la Salud de las Mujeres, suplemento de Contraception 75(6S): S1-S166, en español, abril 2008.

Fifth International Symposium on Intrauterine Devices and Systems for Women's Health, supplement to Contraception 75(6S): S1-S166, June 2007.

Mishell, Daniel R. Jr. 2007. “Intrauterine contraception: An under-utilized method of family planning," European Journal of Contraception and Reproductive Health Care 12(1): 1-2.

\section{OUTSIDE FUNDING}

Barr Pharmaceuticals (unrestricted educational grant), Berlex, Inc. (unrestricted educational grant), and United Nations Population Fund (Spanish translation of the supplement to Contraception)
} 


\section{Council Researcher Studies Egyptian Economic Paradox}

In the past decade, Egypt has seen a decline in the rate of unemployment. At the same time, however, the poverty rate has remained stable or has even increased. This apparent contradiction "is puzzling to many and understandably has been met with a degree of skepticism, if not outright rejection," writes social scientist Ragui Assaad in a recent analysis. To solve the mystery, Assaad examined data from one of the best sources of information on the workforce in Egypt, the Egypt Labor Market Panel Survey.

At the time of his research, Assaad was the Population Council's Cairo-based regional director for West Asia and North Africa. He is now a senior consultant to the Council and has returned to his position as professor at the Humphrey Institute of Public Affairs, University of Minnesota.

The Egypt Labor Market Panel Survey of 2006, carried out between January and March 2006, is a follow-up to the Egypt Labor Market Survey of 1998, carried out between November and December 1998. The 1998 survey involved a nationally representative sample of 4,816 households. The final sample from the 2006 survey of 8,349 households is made up of:

- 3,684 households from the original 1998 survey;

- 2,167 new households that emerged as a result of splits from the original households; and

- a refresher sample of 2,498 households (to ensure that the data remain nationally representative).

Of the 23,997 individuals interviewed in 1998, 17,357 (72 percent) were successfully reinterviewed in 2006.

\section{Is unemployment actually down?}

"According to six different estimates based on various definitions of unemployment and of economic activity, unemployment has declined across the board in the 1998-2006 period, after having risen significantly in the 1988-1998 period," writes Assaad. "Although the decline is

fairly broad, cutting across urban and rural areas, and across regions, rural areas appear to have experienced a sharper decline in unemployment than urban areas. Most surprisingly, the decline is greatest in rural Upper Egypt.” Rural Upper Egypt is the poorest part of the country.

The highest rates of unemployment in 1998, 33 percent, were among rural women. By 2006, however, rural female unemployment

Young women and

young men face very

different obstacles.

had dropped significantly, to 17 percent. It is now lower than the figure of 20 percent among urban women. The sharpest drop in the number of rural unemployed women was among those whose only approach to looking for work was to register at a government employment office. "This is a clear indication that many educated rural women who were queuing for government jobs in 1998 have given up hope of getting such jobs and are now simply not seeking work at all," writes Assaad.

Similarly, Assaad found that in 1998 unemployment levels were low for people with low levels of education, highest among technical secondary school graduates, and somewhat lower for those who attended a postsecondary institution or had graduated from college. In 2006, unemployment rates remained low for people with low levels of education, were higher for technical secondary graduates, and even higher for post-secondary and college graduates. The last group is the only one to have experienced an increase in unemployment between 1998 and 2006.

"Until recently," Assaad explains, "the government had a major role in employing firsttime entrants to the labor market, especially educated entrants. And now, as the economy is switching to more of a market orientation, the formal or the large-scale private sector is not providing the employment opportunities that the government used to provide. Young people are being employed by small-scale private firms, family farms, enterprises that are in the range of one to nine workers. So, a lot of young people are finding themselves either relegated to working for their own families as unpaid workers, or working for very small enterprises at very low levels of productivity. They are not getting social insurance coverage, not getting any kind of social protection that typically comes with jobs."

Thus, much of the drop in unemployment may be due to people exiting the labor force as a result of discouragement rather than due to their being employed. This, along with the transition to lower-quality jobs, explains the continued stagnation of the poverty rate in Egypt, despite a drop in unemployment. "It's not just whether or not you have a job, but does this job come with social protection? Does it support a decent standard of living?" Assaad says. "The Population Council has a lot of activities in Egypt right now centered on understanding the experiences of young people attempting to enter the workforce. That research involves understanding how labor markets function, understanding how poverty interacts with labor markets, and understanding the barriers that young people face in the labor market, especially in terms of gender. The fact is that young women and young men face very different obstacles as they make their transition to employment. The Council is working hard to understand and improve this situation."

\footnotetext{
SOURCE

Assaad, Ragui. 2008. "Unemployment and youth insertion in the labor market in Egypt," in Hanna KheirEl-Din (ed.), The Egyptian Economy, Current Challenges and Future Prospects. An Egyptian Center for Economic Studies Publication. The American University in Cairo Press, Chapter 5, pp.133-178.

\section{OUTSIDE FUNDING}

Egyptian Center for Economic Studies, Ford Foundation, and United States Agency for International Development
} 


\section{Self-sampling for RTIs Is Valid, Feasible, Acceptable}

G lobally, new cases of syphilis, gonorrhea, chlamydia, and trichomoniasis total 340 million each year. Sexually transmitted infections (STIs) and other reproductive tract infections (RTIs) are major causes of severe illness, infertility, obstetric complications, and infant illness. They may also increase transmission of HIV. Gonorrhea and chlamydia are 50 to 300 percent more prevalent among women than among men. Correctly diagnosing and treating RTIs in women is thus a public health imperative. However, reaching this goal usually requires a clinic visit and a pelvic examination, which may deter some women. Population Council researchers investigated the acceptability and feasibility of home-based selfsampling for STIs in Brazil and South Africa. In South Africa, Council researchers also looked at the validity of using self-sampling in a clinic setting to diagnose RTIs.

\section{An alternative approach}

Syndromic management is an inexpensive strategy for diagnosing infection based on the presence of vaginal discharge, lower abdominal pain, or other symptoms, signs, or risk factors, rather than on laboratory tests. However, research by the Population Council and others has shown that syndromic management is not effective for diagnosing or managing RTIs among women. One reason for this is that not all women with symptoms actually have an RTI, and not all women with RTIs have symptoms. Home selfsampling, combined with laboratory tests, is a possible alternative. The use of laboratory tests would provide greater accuracy than syndromic management. The use of self-sampling at home might be more acceptable to women who wish to avoid a pelvic exam, and would also be cheaper than conducting an exam in a clinic. Using this method, clinics could test women regardless of whether they have symptoms, and treat only those who really need it.

Population Council researchers* Heidi E. Jones, Sheri A. Lippman, Janneke H.H.M. van de Wijgert, and Juan Diaz collaborated with colleagues from Santa Casa Medical School in São Paulo and the University of Cape Town.
The researchers conducted two studies in South Africa and one in Brazil.

\section{Self-sampling is valid, feasible, and acceptable}

In the first study in South Africa, 450 women were randomly assigned to use either an ordinary tampon or a vaginal swab to collect samples at the clinic, which were later tested for trichomoniasis (a protozoal infection), chlamydia and gonorrhea (both bacterial infections), bacterial vaginosis (an imbalance of naturally occurring bacteria in the vagina), candidiasis (a fungal infection), and high-risk human papillomaviruses (HPV, which can lead to cervical cancer). Nurses also took samples during pelvic exams of all the women to test the validity of these self-collected specimens.

The researchers found that self-sampling resulted in satisfactory validity for detection of gonorrhea, chlamydia, bacterial vaginosis, and candidiasis when tested with molecular tests or microscopy. For high-risk HPV only the swabs were adequate using one of the laboratory tests (Digene Hybrid Capture II), but both the tampon and swab were acceptable when a second test (Roche Reverse Line Blot Assay) was used. Culturing for trichomoniasis after selfsampling was not successful. While selfsampling was feasible and acceptable for most RTIs, some women preferred vaginal examinations by a clinician.

For the second study, 818 women in Brazil and 626 women in South Africa were randomly assigned to receive a clinic appointment or a kit for home-based self-collection and testing for STIs. All the women doing self-testing collected two vaginal swabs. One swab was mailed to the laboratory for detection of chlamydia, gonorrhea, and trichomoniasis; the other was used for a selfconducted rapid test for trichomoniasis.

In Brazil, the researchers found that slightly more women responded to the initiative within two weeks in the home group (80 percent) than in the clinic group ( 76 percent). Younger women were more responsive to home-based screening than were older women.
Ninety-four percent of home-group participants successfully completed self-collection and selftesting on their first attempt. Similarly, in South Africa, slightly more women mailed in their kit (47 percent) than kept their clinic appointment (42 percent). An additional group of women partially completed the home kit (13 percent).

The researchers concluded in all studies that home-based self-collection and self-testing is acceptable and feasible in resource-poor settings, and is a promising alternative to clinic-based STI screening and syndromic management. Further, integrating these options into STI services could increase the number of women screened, and should be explored as effective rapid diagnostics become available.

\section{SOURCES}

Jones, Heidi E., Bruce R. Allan, Janneke H. H. M. van de Wijgert, Lydia Altini, Sylvia M. Taylor, Alana de Kock, Nicol Coetzee, and Anna-Lise Williamson. 2007. "Agreement between self- and clinician-collected specimen results for detection and typing of high-risk human papillomavirus in specimens from women in Gugulethu, South Africa," Journal of Clinical Microbiology 45(6):1679-1683.

Jones, H. E., L. Altini, A. de Kock, T. Young, and J. H. H. M. van de Wijgert. 2007. "Home-based versus clinic-based self-sampling and testing for sexually transmitted infections in Gugulethu, South Africa: Randomised controlled trial," Sexually Transmitted Infections 83(7):552-557.

Lippman, Sheri A., Heidi E. Jones, Carla G. Luppi, Adriana A. Pinho, Maria Amelia M. S. Veras, and Janneke H. H. M. van de Wijgert. 2007. "Home-based self-sampling and self-testing for sexually transmitted infections: Acceptable and feasible alternatives to provider-based screening in low-income women in São Paulo, Brazil," Sexually Transmitted Diseases 34(7): 421-428.

van de Wijgert, Janneke, Lydia Altini, Heidi Jones, Alana de Kock, Taryn Young, Anna-Lise Williamson, Anwar Hoosen, and Nicol Coetzee. 2006. "Two methods of self-sampling compared to clinician sampling to detect reproductive tract infections in Gugulethu, South Africa," Sexually Transmitted Diseases 33(8): 516-523.

\section{OUTSIDE FUNDING}

United States Agency for International Development, the Parthenon Trust, and the William and Flora Hewlett Foundation

\footnotetext{
*These researchers have since left the Council. Jones is at Columbia University; Lippman at the University of California; van de Wijgert at the University of Amsterdam; and Diaz at Reprolatina.
} 


\section{Straight Talk Increases Knowledge, Improves Behavior}

The Straight Talk mass media program has been bringing information about HIV and reproductive health to young people in Uganda since 1993. The program is considered one of the most successful ongoing media efforts of its kind. But are its messages reaching young people and having a positive impact on their attitudes and behaviors? In 2005-2006, the Population Council's USAID-funded Horizons Program conducted the first evaluation of Straight Talk to document its effects on young people, with partners PATH, the International Center for Research on Women, and Makerere University. The assessment focused particularly on the relationships between exposure to Straight Talk media and healthy behaviors.

The main part of the evaluation involved a survey of 1,019 girls and 1,021 boys between the ages of 10 and 19 years. Data were collected between 29 August and 7 September 2005 in six districts in Uganda.

Straight Talk produces various media products, primarily multilingual Straight Talk radio shows, multilingual Straight Talk newspapers, and an English-language Young Talk newspaper. Straight Talk also conducts school-based activities to engender a youthfriendly school environment.

\section{Straight Talk materials used widely}

The survey shows that Straight Talk materials have reached virtually all secondary and twothirds of primary school students, as well as 56 percent of out-of-school young people. Adding local-language Straight Talk products doubles exposure, showing the value of these products in a multilingual country such as Uganda. Nearly 60 percent of adolescents who were familiar with Straight Talk reported that the main message they had gotten was about the importance of abstinence. The Straight Talk materials and programs advocate a variety of HIV riskreduction strategies including abstinence, monogamy, condom use, and knowledge of one's HIV status through voluntary testing for and counseling about HIV.
"The results suggest that greater exposure to Straight Talk products is significantly associated with higher reproductive health knowledge," said Karusa Kiragu of Horizons/ PATH (now of UNAIDS). Kiragu was one of the principal investigators on the study. "Each incremental exposure to Straight Talk is associated with increased knowledge. This relationship holds for both boys and girls."

\section{Sexual activity and condom use}

About one-fourth of the respondents said that they had a boyfriend or girlfriend, and 12 percent of the study sample had ever had sex (15 percent of boys and 9 percent of girls). Among boys, those exposed to all three Straight Talk media products were 61 percent less likely to be sexually active than boys unexposed to Straight Talk. Among girls, the pattern was not clear or statistically significant, in part because so few girls were sexually active. Among adolescents who had ever had sex, about 38 percent of boys and 41 percent of girls had not had sex in the 12 months before the survey. They were thus practicing "secondary abstinence." The boys who had the highest level of exposure to Straight Talk were three times more likely to report practicing secondary abstinence than were boys unexposed to Straight Talk.

Two keys to HIV prevention are condom use and knowledge about one's HIV status. Half of the sexually experienced girls and 41 percent of such boys reported having used condoms at their last intercourse. While twothirds of the boys reported being responsible for using condoms, more than half the girls reported taking the initiative to use them. Exposure to Straight Talk was clearly associated with having been tested for HIV and with knowing whether a partner had been tested. Among respondents who had been exposed to all three Straight Talk products, boys were 4 times as likely and girls were 3.5 times as likely as unexposed adolescents to have been tested for HIV.
For girls, exposure to Straight Talk materials is associated with greater selfassuredness, greater sense of gender equity, and the likelihood of having a boyfriend but not having a sexual relationship. Among boys, Straight Talk exposure is associated with lower likelihood of sexual activity, greater likelihood of resuming abstinence, and a greater likelihood of taking relationships with girls seriously.

Among both boys and girls, exposure to Straight Talk activities is associated with greater sexual and reproductive health knowledge and more communication with parents about sexual and reproductive health issues. Both girls and boys exposed to all three Straight Talk products were about four times as likely as unexposed adolescents to have talked with parents about reproductive health matters. The research suggests, however, that many parents need help to feel comfortable engaging in such conversations. Parents were asked about talking with their children about "sexuality, growing up, relationships." Although 45 percent said they preferred that their child speak to a parent, 55 percent said they preferred that their child go elsewhere for such information.

"Straight Talk may have protected many boys and girls from HIV by helping them to stop sexual activity or to delay starting it all together," concluded Tobey Nelson Sapiano, of Horizons/ICRW, another principal investigator on the study.

\footnotetext{
SOURCES

Adamchak, Susan E., Karusa Kiragu, Cathy Watson, Medard Muhwezi, Tobey Nelson Sapiano, Ann AkiaFiedler, Richard Kibombo, and Milka Juma. 2008.

"Helping youth prevent HIV: An evaluation of the Straight Talk program in Uganda," Horizons Research Summary. Washington, DC: Population Council.

Adamchak, Susan E., Karusa Kiragu, Cathy Watson, Medard Muhwezi, Tobey Nelson Sapiano, Ann AkiaFiedler, Richard Kibombo, and Milka Juma. 2007.

"The Straight Talk campaign in Uganda: The impact of mass media initiatives," Horizons Final Report. Washington, DC: Population Council.

OUTSIDE FUNDING

United States Agency for International Development
} 


\section{HIV AND AIDS}

Adamchak, Susan E., Karusa Kiragu, Cathy Watson, Medard Muhwezi, Tobey Nelson Sapiano, Ann Akia-Fiedler, Richard Kibombo, and Milka Juma. "Helping youth prevent HIV: An evaluation of the Straight Talk program in Uganda," Horizons Research Summary. Washington, DC: Population Council.

Bharat, Shalini and Vaishali Sharma Mahendra. 2007

"Meeting the sexual and reproductive health needs of people living with HIV: Challenges for health care providers, Reproductive Health Matters 15(29, supplement 1): 93-112. Bollen, Liesbeth J. M., Kelly Blanchard, Peter H. Kilmarx, Supaporn Chaikummao, Cathy Connolly, Punneporn Wasinrapee, Nucharee Srivirojana, Jullapong Achalapong, Jordan W. Tappero, and Janet M. McNicholl. "No increase in cervicovaginal proinflammatory cytokines after Carraguard use in a placebo-controlled randomized clinical trial," Journal of Acquired Immune Deficiency Syndromes 47(2): 253-257.

Chinaglia, Magda, Sheri A. Lippman, Julie Pulerwitz, Maeve de Mello, Rick Homan, and Juan Díaz. 2007. "Reaching truckers in Brazil with non-stigmatizing and effective HIV/STI services," Horizons Research Summary. Washington, DC: Population Council.

Chinaglia, Magda, Waimar Tun, Maeve Mello, Magdalena Insfran, and Juan Díaz. "Assessment of risk factors for HIV infection in female sex workers and men who have sex with men at the triple-border area of Ciudad del Este, Paraguay," Horizons Final Report. Washington, DC: Population Council.

CORO and Horizons/Population Council. Sakhi Saheli: Promoting Gender Equity and Empowering Young Women-A Training Manual. New Delhi: Population Council.

Denison, Julie, Ann P. McCauley, Wendy A. Dunnett-Dagg, Nalakwanji Lungu, and Michael D. Sweat. "The HIV testing experiences of adolescents in Ndola, Zambia: Do families and friends matter?" AIDS Care 20(1): 101-105.

Denison, Julie, Kevin R. O'Reilly, George P. Schmid, Caitlin E. Kennedy, and Michael D. Sweat. "HIV voluntary counseling and testing and behavioral risk reduction in developing countries: A meta-analysis, 1990-2005," AIDS and Behavior 12(3): 363-373.

“Findings from the field: A compilation to date of publications on HIV/AIDS from the Horizons Program, updated March 2008," CD-ROM. Washington, DC: Population Council.

Frank, Ines, Hella Stössel, Agegnehu Gettie, Stuart G. Turville, Julian W. Bess Jr., Jeffrey D. Lifson, Irving Sivin, Nikolaus Romani, and Melissa Robbiani. “A fusion inhibitor prevents spread of immunodeficiency viruses, but not activation of virus-specific T cells, by dendritic cells," Journal of Virology 82(11): 5329-5339.

Homan, Rick, Desai Jaikishan, Paul Munyao, Avina Sarna, and Scott Geibel. 2007. "Impact of antiretroviral therapy on household economics: Findings from Mombasa, Kenya," Horizons Research Summary. Nairobi: Population Council. "Horizons operations research toolkit on HIV/AIDS," CD-ROM. Washington, DC: Population Council.

“Informed consent in HIV prevention trials: Highlights from an international workshop." New York: Population Council. (Also available in French, Portuguese, and Spanish)

Kaai, Susan, Avina Sarna, Stanley Luchters, Scott Geibel, Paul Munyao, Kishor Mandaliya, Khadija Shikely, Marleen Temmerman, and Naomi Rutenberg. 2007. “Changes in stigma among a cohort of people on antiretroviral therapy: Findings from Mombasa, Kenya," Horizons Research Summary. Nairobi: Population Council.

Kerrigan, Deanna, Paulo Telles, Helena Torres, Cheryl Overs, and Christopher Castle. "Community development and HIV/STI-related vulnerability among female sex workers in Rio de Janeiro, Brazil," Health Education Research 23(1): 137-145.

Khan, Hena, Carolyn Baek, Vuyiswa Mathambo, Sibongile Mkhize, Irwin Friedman, Louis Apicella, and Naomi Rutenberg. 2007. "From mother to mother: A peer mentor programme to prevent mother-to-child transmission of HIV in South Africa offers much needed support," SAfAIDS 13(3): 6-7.

Kilmarx, Peter H., Kelly Blanchard, Supaporn Chaikummao, Barbara A. Friedland, Nucharee Srivirojana, Cathy Connolly, Paisit Witwatwongwana, Somsak Supawitkul, Philip A. Mock, Thanyanan Chaowanachan, and Jordan W. Tappero. "A randomized, placebo-controlled trial to assess the safety and acceptability of use of Carraguard vaginal gel by heterosexual couples in Thailand," Sexually Transmitted Diseases 35(3): 226-232.

Luchters, Stanley, Avina Sarna, Scott Geibel, Matthew Chersich, Paul Munyao, Susan Kaai, Kishor Mandaliya, Naomi Rutenberg, and Marleen Temmerman. 2007. “Sexual risk behaviors of HIV-positive persons receiving ART in Mombasa, Kenya: Longitudinal study findings," Horizons Research Summary. Nairobi: Population Council.

Maganja, R.K., Suzanne Maman, Allison Groves, and Jesse K. Mbwambo. 2007. "Skinning the goat and pulling the load: Transactional sex among youth in Dar es Salaam, Tanzania," AIDS Care 19(8): 974-981.

Moreau, Amadou, Placide Tapsoba, Abdoulaye Ly, Cheikh Ibrahima Niang, and Abdou Khoudia Diop. 2007.

"Implementing STI/HIV prevention and care interventions for men who have sex with men in Senegal," Horizons Research Summary. Washington, DC: Population Council.

Nelson, Tobey C., Eka Esu-Williams, Lungile Mchunu, Pinkie Nyamakazi, S'Fiso Mnguni, Katie Schenk, Catherine Searle, and Jennifer Redner. "Training youth caregivers to provide HIV education and support to orphans and vulnerable children in South Africa," Horizons Research Summary. Washington, DC: Population Council.

Nyblade, Laura, Kerry MacQuarrie, Gideon Kwesigabo, Aparna Jain, Lusajo Kajula, Fausta Philip, William Henerico Tibesigwa, and Jessie Mbwambo. "Moving forward: Tackling stigma in a Tanzanian community," Horizons Final Report. Washington, DC: Population Council.

Oanh, Khuat Thi Hai, Kim Ashburn, Julie Pulerwitz, Jessica Ogden, and Laura Nyblade. "Improving hospital-based quality of care in Vietnam by reducing HIV-related stigma and discrimination," Horizons Final Report. Washington, DC: Population Council.

Pulerwitz, Julie and Gary Barker. "Measuring attitudes toward gender norms among young men in Brazil: Development and psychometric evaluation of the GEM scale," Men and Masculinities 10(3): 322-338.

Samuels, Fiona, Joseph Simbaya, Avina Sarna, Scott Geibel, Phillimon Ndubani, and Jolly Kamwanga. "Engaging communities in supporting HIV prevention and adherence to antiretroviral therapy in Zambia," Horizons Research Summary. Washington, DC: Population Council.

\section{Sapiano, Tobey Nelson, Nathi Sohaba, and Eka Esu-Williams.} "'Dare to Be Different': Enhancing life skills education for HIV prevention in South African schools," Horizons Research Summary. Washington, DC: Population Council.

Sarna, Avina, Stanley Luchters, Scott Geibel, Matthew Chersich, Paul Munyao, Rick Homan, Susan Kaai, Kishor Mandaliya, Marleen Temmerman, and Naomi Rutenberg. 2007. "Promoting adherence through a directly administered antiretroviral therapy strategy in Mombasa, Kenya," Horizons Research Summary. Nairobi: Population Council.

Sarna, Avina, Stanley Luchters, Scott Geibel, Susan Kaai, Paul Munyao, Khadija Shikely, Kishor Mandaliya, C. Johannes van Dam, and Marleen Temmerman. "Sexual risk behavior and HAART: A comparative study of HIV-infected persons on HAART and on preventive therapy in Kenya," International Journal of STD and AIDS 19(2): 85-89.

Sarna, Avina, Sanjay Pujari, A.K. Sengar, Rajiv Garg, Indrani Gupta, and C. Johannes van Dam. "Adherence to antiretroviral therapy and its determinants amongst HIV patients in India," Indian Journal of Medical Research 127(1): 28-36.

Schenk, Katie D., Lewis Ndhlovu, Stephen Tembo, Andson Nsune, Chozi Nkhata, Batuke Walusiku, and Charlotte Watts. "Circumstances and motivations for fostering children in Zambia," Vulnerable Child and Youth Studies 3(1): 78-84. Sprague, Wendy S., Melissa Robbiani, Paul R. Avery, Kevin P. $\mathrm{O}^{\prime}$ Halloran, and Edward A. Hoover. "Feline immunodeficiency virus dendritic cell infection and transfer," Journal of General Virology 89(3): 709-715.

Thurman, Tonya, Leslie Snider, Neil Boris, Edward Kalisa Laetitia Nyirazinyoye, and Lisanne Brown. "Barriers to the community support of orphans and vulnerable youth in Rwanda," Social Science and Medicine 66(7): 1557-1567. Turville, Stuart G., Meropi Aravantinou, Hella Stössel, Nikolaus Romani, and Melissa Robbiani. "Resolution of $d e$ novo HIV production and trafficking in immature dendritic cells," Nature Methods 5(1): 75-85. van de Wijgert, Janneke H.H.M., Peter H. Kilmarx, Heidi E. Jones, John M. Karon, and Supaporn Chaikummao. “Differentiating normal from abnormal rates of genital epithelial findings in vaginal microbicide trials," Contraception 77(2): 122-129

Viravaidya, Mechai, R.C. Wolf, and Philip Guest. "An assessment of the Positive Partnership Project in Thailand: Key considerations for scaling-up microcredit loans for HIVpositive and negative pairs in other settings," Global Public Health 3(2): 115-136.

Warren, Charlotte, Rachel Shongwe, Allen Waligo, Mohammed Mahdi, Goldy Mazia, and Indira Narayanan. "Repositioning postnatal care in a high HIV environment: Swaziland," Horizons Final Report. Washington, DC: Population Council.

\section{POVERTY, GENDER, ANDYOUTH}

Alexander, Mallika, Laila Garda, Savita Kanade, Shireen J. Jejeebhoy, and Bela Ganatra. 2007. “Correlates of premarital relationships among unmarried youth in Pune District, Maharashtra, India," International Family Planning Perspectives 33(4): 150-159.

Amin, Sajeda. 2007. “Bangladesh: Achieving universal primary education at the end of the 20th century," in A. Gupta (ed.) Schooling Around the World: South Asia. New York: Routledge. . "Enhancing the benefits of girls' livelihood initiatives," Promoting Healthy, Safe, and Productive Transitions to Adulthood Brief no. 17. New York: Population Council. (updated January 2008) (Also available in French, Spanish, and Portuguese)

"Reforming marriage practices in Bangladesh," Promoting Healthy, Safe, and Productive Transitions to Adulthood Brief no. 31. New York: Population Council.

Amin, Sajeda, Erica Chong, and Nicole Haberland. "Programs to address child marriage: Framing the problem," Promoting Healthy, Safe, and Productive Transitions to Adulthood Brief no. 14. New York: Population Council. (updated January 2008) (Also available in French)

Amin, Sajeda and Luciana Suran. "Terms of marriage and time-use patterns of young wives: Evidence from rural Bangladesh," Poverty, Gender, and Youth Working Paper no. 10. New York: Population Council.

Assaad, Ragui. "Unemployment and youth insertion in the labor market in Egypt," in Hanaa Kheir-El-Din (ed.), The Egyptian Economy, Current Challenges and Future Prospects. Cairo: The American University in Cairo Press, pp. 133-178.

Austrian, Karen. 2007. “Expanding safe spaces and developing skills for adolescent girls," Promoting Healthy, Safe, and Productive Transitions to Adulthood Brief no. 29 New York: Population Council. (Also available in Portuguese) Bongaarts, John. 2007. "The causes of stalling fertility," in Azmal Hussain (ed.), Demographic Transition: A Global Perspective. Hyderabad: Icfai University Press.

“Fertility transitions in developing countries: Progress or stagnation?" Studies in Family Planning 39(2): 105-110. Also issued as Poverty, Gender, and Youth Working Paper no. 7. New York: Population Council.

"Food and population: The return of Malthus?" commentary. New York: Population Council.

Bongaarts, John, Thomas Buettner, Gerhard Heilig, and François Pelletier. "Has the HIV epidemic peaked? Population and Development Review34(2): 199-224. Also issued as Poverty, Gender, and Youth Working Paper no. 9. New York: Population Council.

Brady, Martha. 2007. "Leveling the playing field: Building girls' sports programs in the developing world," Promoting Healthy, Safe, and Productive Transitions to Adulthood Brief no. 1. New York: Population Council. (updated October 2007) (Also available in Portuguese)

Brady, Martha, Abeer Salem, and Nadia Zibani. 2007. "Bringing new opportunities to adolescent girls in socially conservative settings: The Ishraq program in rural Upper Egypt," Promoting Healthy, Safe, and Productive Transitions to Adulthood Brief no. 12. New York: Population Council. (updated August 2007)

Brady, Martha and Lydia Saloucou. 2007. "Addressing the needs of married adolescent girls in Burkina Faso," Promoting Healthy, Safe, and Productive Transitions to Adulthood Brief no. 9. New York: Population Council. (updated July 2007) (Also available in French) 
Bruce, Judith. 2007. "Child marriage in the context of the HIV epidemic," Promoting Healthy, Safe, and Productive Transitions to Adulthood Brief no. 11. New York: Population Council. (updated September 2007) (Also available in Portuguese)

. 2007. "Girls left behind: Redirecting HIV interventions toward the most vulnerable," Promoting Healthy, Safe, and Productive Transitions to Adulthood Briefno. 23. New York: Population Council. (Also available in French, Portuguese, and Spanish)

Bruce, Judith and Kelly Hallman. "Reaching the girls left behind," Gender and Development 16(2): 227-245.

Casterline, John B. and Rania Roushdy. 2007. “Slow fertility transition in Egypt." Cairo: Population Council.

Chandrasekhar, S. and Abhiroop Mukhopadhyay. "Multiple dimensions of urban well-being: Evidence from India," Poverty, Gender, and Youth Working Paperno. 11. New York: Population Council.

Erulkar, Annabel S. and Mairo Bello. 2007. “The experience of married adolescent girls in northern Nigeria." Abuja: Population Council.

Erulkar, Annabel S. and Tekle-Ab Mekbib. 2007. “Reaching vulnerable youth in Ethiopia," Promoting Healthy, Safe, and Productive Transitions to Adulthood Brief no. 6. New York: Population Council. (updated August 2007)

Erulkar, Annabel S., Tekle-Ab Mekbib, Helen Amdemikael, and Garry Conille. 2007. "Leave no woman behind, Ethiopia: Baseline report." Addis Ababa: Population Council.

Erulkar, Annabel S., Tekle-Ab Mekbib, and Mesfin Tegegne. “Biruh Tesfa: Creating a 'Bright Future' for migrant girls in urban areas of Ethiopia," Promoting Healthy, Safe, and Productive Transitions to Adulthood Briefno. 21. New York: Population Council. (updated January 2008)

Erulkar, Annabel S. and E. Muthengi. "Evaluation of Berhane Hewan: A pilot program to promote education and delay marriage in rural Ethiopia." Addis Ababa: Population Council. Haberland, Nicole. 2007. “Supporting married girls: Calling attention to a neglected group," Promoting Healthy, Safe, and Productive Transitions to Adulthood Brief no 3. New York: Population Council. (Also available in French and Spanish)

Haberland, Nicole and Deborah Rogow. 2007. "Sexuality and HIV education: Time for a paradigm shift," Promoting Healthy, Safe, and Productive Transitions to Adulthood Brief no 22. New York: Population Council. (Also available in French and Spanish) Hallman, Kelly. 2007. “Nonconsensual sex, school enrollment and educational outcomes in South Africa," Africa Insight 37(3): 454-472.

Hallman, Kelly, Kasthuri Govender, Eva Roca, Rob Pattman, Emmanuel Mbatha, and Deevia Bhana. 2007. “Enhancing financial literacy, HIV/AIDS skills, and safe social spaces among vulnerable South African youth," Promoting Healthy, Safe, and Productive Transitions to Adulthood Brief no. 4. New York: Population Council. (updated September 2007) (Also available in French)

Hallman, Kelly, Sara Peracca, Jennifer Catino, and Marta Julia Ruiz. 2007. "Assessing the multiple disadvantages of Mayan girls: The effects of gender, ethnicity, poverty, and residence on education in Guatemala," Promoting Healthy, Safe, and Productive Transitions to Adulthood Brief no. 16. New York: Population Council. (updated June 2007) (Also available in Spanish)

Hallman, Kelly and Eva Roca. 2007. "Reducing the social exclusion of girls," Promoting Healthy, Safe, and Productive Transitions to Adulthood Brief no. 27. New York: Population Council. (Also available in Spanish)

Hallman, Kelly, Eva Roca, Marta Julia Ruiz, Jennifer Catino Alejandra Colom, and Sandra Contreras Aprile. 2007. "For Mayan girls, safe spaces lead to social gains," Promoting Healthy, Safe, and Productive Transitions to Adulthood Brief no. 5. New York: Population Council. (updated September 2007) (Also available in Spanish)

Hewett, Paul C. "Review of Duane F. Alwin, Margins of Error: A Study of Reliability in Survey Measurement," Population and Development Review34(1): 10.

Jejeebhoy, Shireen J. 2007. “Understanding sex without consent among young people: A neglected priority, Promoting Healthy, Safe, and Productive Transitions to Adulthood Brief no. 7. New York: Population Council. (updated July 2007) (Also available in French and Spanish)

Kenworthy, Nora, Kelly Hallman, and Judith A. Diers. "Identifying sources of adolescent exclusion due to violence: Participatory mapping in South Africa," Promoting Healthy, Safe, and Productive Transitions to Adulthood Brief no. 30. New York: Population Council.

Knodel, John, Vu Tuan Huy, Vu Manh Loi, and Sharon Ghuman. 2007. "Vietnamese aging and marital sexual behavior in comparative perspective," Asian Population Studies 3(1): 57-78. Levine, Ruth, Cynthia B. Lloyd, Margaret Greene, and Caren Grown. Girls Count: A Global Investment and Action Agenda. Washington, DC: Center for Global Development.

Lloyd, Cynthia B. 2007. “Girls' schooling in developing countries: Highlights from Population Council research," Promoting Healthy, Safe, and Productive Transitions to Adulthood Brief no. 24. New York: Population Council. (Also available in Spanish) "Education during humanitarian emergencies: The situation of displaced children and youth in Darfur, Sudan, Promoting Healthy, Safe, and Productive Transitions to Adulthood Brief no. 32. New York: Population Council. Lloyd, Cynthia B., Monica J. Grant, and Amanda Ritchie. "Gender differences in time use among adolescents in developing countries: Implications of rising school enrollment rates," Journal of Research on Adolescence 18(1): 99-120.

Lloyd, Cynthia B. and Barbara S. Mensch. "Marriage and childbirth as factors in dropping out from school: An analysis of DHS data from sub-Saharan Africa," Population Studies 62(1): 1-13.

Martine, George, Gordon McGranahan, Mark R. Montgomery, and Rogelio Fernández-Castilla (eds.). The New Global Frontier: Urbanization, Poverty and Environment in the 21st Century, London: Earthscan Publishers.

Mensch, Barbara S. 2007. "The changing context of sexua initiation in sub-Saharan Africa," Promoting Healthy, Safe, and Productive Transitions to Adulthood Brief no. 26. New York: Population Council. (Also available in French)

Mensch, Barbara S., Paul C. Hewett, Richard Gregory, and Stephane Helleringer. "Sexual behavior and STI/HIV status among adolescents in rural Malawi: An evaluation of the effect of interview mode on reporting," Poverty, Gender, and Youth Working Paper no. 8. New York: Population Council.

Mir, Ali Mohammad and Gul Rashida. "Challenging the gender paradigm in rural Pakistan: A case study of empowered lady health workers," in Laura Reichenbach (ed.), Exploring the Gender Dimensions of the Global Health Workforce. Cambridge, MA: Global Equity Initiative, Harvard University.

Montgomery, Mark R. “The urban transformation of the developing world," Science 319(5864): 761-764.

Ochieng, Bentinck, Annabel S. Erulkar, James Matheka, and Lawrence Oteba. 2007. "Friends of Youth: A youth-adult HIV/AIDS behavior change program for urban Kenyan youth" Program Brief: Kenya. Nairobi: Population Council.

"The Population Council's approach," Promoting Healthy, Safe, and Productive Transitions to Adulthood Brief Overview. New York: Population Council, 2007. (updated September 2007) (Also available in French, Portuguese, and Spanish)

Salem, Abeer and Nadia Zibani. 2007. "The Ishraq Program: Reshaping gender norms in rural upper Egypt," ISSBD Newsletter no. 52(2): 1-5.

Teerawichitchainan, Bussarawan, Hac Van Vinh, and Nguyen Thi Phuong Lan. 2007. “Changing transitions to adulthood in Vietnam's remote northern uplands: A focus on ethnic minority youth and their families." Hanoi: Population Council.

Teerawichitchainan, Bussarawan and James F. Phillips. "Ethnic differentials in parental health seeking for childhood illness in Vietnam," Social Science and Medicine 66(5): 1118-1130.

"Unmet need for family planning," GEMI (Ghana Essential Medicines Initiative) Progress Report, Winter. Accra: Population Council.

"Youth in India: Situation and needs - Key indicators, 2006-2007: Jharkhand," fact sheet. New Delhi: Population Council, 2007.

"Youth in India: Situation and needs - Key indicators, 2006-2007: Tamil Nadu," fact sheet. New Delhi: Population Council, 2007

Zibani, Nadia. 2007. “From the field gender equality: The Ishraq Program," Sport for Development and Peace International Working Group (SDP IWG). Toronto: Right to Play.

\section{REPRODUCTIVE HEALTH}

Abdi, Maryam Sheikh, Guyo Jaldesa, and lan Askew. "Managing and preventing female genital cutting (FGM/C) among the Somali community in Kenya," FRONTIERS Final Report. Washington, DC: Population Council.

"Africa regional sexual and gender-based violence network consultation: Technical exchange and planning meeting," report of a meeting at Roode Vallei Lodge, Pretoria, South Africa, 5-7 March. Nairobi: Population Council.

Anwar, Md. Mahabub UI, Ubaidur Rob, Ismat Ara Hena,
Mohammad Masudul Alam, Mohammad Ainul Haque, and Mohammad Ataur Rahman. "Increasing the rational use of modern contraceptive methods during the reproductive life cycle," DBRHCP Research Update no. 2. Dhaka: Population Council.

Askew, lan. 2007. "Achieving synergies in prevention through linking sexual and reproductive health and HIV services," in Donta Balaiah (ed.), Strengthening Linkages between Sexual and Reproductive Health and HIV/AIDS. Mumbai: Indian Society for the Study of Reproduction and Fertility and World Health Organization.

Birungi, Harriet. 2007. “HIV/AIDS programming and sexuality of young people perinatally infected with HIV," in Donta Balaiah (ed.), Strengthening Linkages between Sexual and Reproductive Health and HIV/AIDS. Mumbai: Indian Society for the Study of Reproduction and Fertility and World Health Organization.

"Bolivia: A gender focus in service delivery improves quality of care," FRONTIERS OR Summary no. 68. Washington, DC: Population Council.

Bruce, Linda and Antonieta Martin. The Balanced Counseling Strategy: A Toolkit for Family Planning Service ProvidersTrainer's Guide. Washington, DC: Population Council. “Burkina Faso: Political will, law enforcement, and educational campaigns appear to be reducing $\mathrm{FGM} / \mathrm{C}$," FRONTIERS OR Summary no. 72. Washington, DC: Population Council.

Chen, Guo-Rong, L. Dong, Renshan Ge, and Matthew P. Hardy 2007. "Relationship between phthalates and testicular dysgenesis syndrome," National Journal of Andrology 13(3): 195-200.

“Consejería: elemento clave en la interrupción legal del embarazo." Mexico City: Secretary of Health.

"Cuando llamar: A fact sheet on misoprostol use, warning signs, and important contact information." Mexico City: Secretary of Health.

Dieng, Thierno, Mohamed Diadhiou, Nafissatou J. Diop, and Youmané Faye. "Assessment of progress of the Postabortion Care Initiative in Francophone Africa," FRONTIERS Final Report. Washington, DC: Population Council.

Diop, Nafissatou J. "Technical assistance to the interagency coordination group seeking to reduce female genital mutilation/cutting," FRONTIERS Final Report. Washington, DC: Population Council.

Diop, Nafissatou J., Zakari Congo, Lydia Saloucou, Ida Tamini, Aina Ouedraogo, and Alphosine Sawadogo. "Analysis of the evolution of the practice of female genital mutilation/cutting in Burkina Faso," FRONTIERS Final Report. Washington, DC:

Population Council. (Also available in French)

Diop, Nafissatou J. and Alioune Diagne. "Improving communication between parents and adolescents on reproductive health and HIV/AIDS," FRONTIERS Final Report. Washington, DC: Population Council.

Diop, Nafissatou J. and Anta Fall Diagne. “Enhancing utilization of the findings from the youth reproductive health project in Senegal," FRONTIERS Final Report. Washington, DC Population Council.

Diop, Nafissatou J., Amadou Moreau, and Hélène Benga.

"Evaluation of the long-term impact of the TOSTAN programme on the abandonment of FGM/C and early marriage: Results from a qualitative study in Senegal,"

FRONTIERS Final Report. Washington, DC: Population Council.

Ditlopo, Prudence, Saiqa Mullick, lan Askew, Ricardo Vernon, Edwin Maroga, Sgidi Sibeko, Mokgethi Tshabalala, Rabbuh Raletsemo, Dean Peacock, and Andrew Levack. 2007.

"Testing the effectiveness of the Men as Partners Program (MAP) in Soweto, South Africa," FRONTIERS Final Report. Washington, DC: Population Council.

“Dominican Republic, Haiti, Nicaragua: Promoting family planning during the postpartum period can increase contraceptive acceptance," FRONTIERS OR Summary no. 74. Washington, DC: Population Council.

“Dominican Republic, Haiti, Nicaragua: Women living with HIV have unmet family planning needs," FRONTIERS OR Summary no. 75. Washington, DC: Population Council.

"Egypt: Postabortion patients in Egypt need more verba anesthesia to relieve their pain," FRONTIERS Asia and Near East Regional OR Summary no. 23. New Delhi: Population Council, 2007.

"Female genital mutilation/cutting: Publications on research in FGM/C - Mutilations génitales féminines/Excision: Publications sur la recherche concernant l'excision," FRONTIERS CDROM. Nairobi: Population Council.

"Financial sustainability of reproductive health NGOs," FRONTIERS CD-ROM. Washington, DC: Population Council. 
Ge, Renshan, Guo-Rong Chen, Cigdem Tanrikut, and Matthew P. Hardy. 2007. "Phthalate ester toxicity in Leydig cells: Developmental timing and dosage considerations," Reproductive Toxicology 23(3): 366-373.

"India: Quality assurance procedure monitors and improves quality of services," FRONTIERS OR Summary no. 76. Washington, DC: Population Council.

Janowitz, Barbara, John Bratt, Rick Homan, and James R. Foreit. 2007. "How much will it cost to scale up a reproductive health pilot project?" FRONTIERS Program Brief no. 8. Washington, DC: Population Council.

"Kenya: Islamic scholars find no religious justification for FGM/C," FRONTIERS OR Summary no. 73. Washington, DC: Population Council.

"Kenya: Training can enhance providers' management of FGM/C and willingness to advocate against the practice," FRONTIERS OR Summary no. 71. Washington, DC: Population Council.

Kenya Ministry of Health. 2007. "Management of complications, pregnancy, childbirth and the postpartum period in the presence of FGM/C." Nairobi: Division of Reproductive Health/Kenya Ministry of Health and Population Council.

Khan, M.E., Anurag Mishra, Vivek Sharma, and Leila Caleb Varkey. "Development of a quality assurance procedure for reproductive health services for district public health systems: Implementation and scale-up in the state of Gujarat,"

FRONTIERS Final Report. Washington, DC: Population Council.

Khan, M.E., Mary Philip Sebastian, and Aditi Aeron.

“Promoting healthy timing and spacing of pregnancy: Barriers and possible intervention-Observation from a qualitative study in Uttar Pradesh," FRONTIERS Asia and Near East Research Update no. 13. New Delhi: Population Council.

Khan, M.E., Mary Philip Sebastian, Rukma Idnani, and Kaushal Kumari. "Promoting postpartum contraception among young low parity women: Some salient findings," FRONTIERS Asia and Near East Research Update no. 14. New Delhi: Population Council.

Khan, M.E., Mary Philip Sebastian, Usha Sharma, Rukma Idnani, Kaushal Kumari, Bharati Maheshwari, and Shahid Ashraf. "Promoting healthy timing and spacing of births in India through a community-based approach," FRONTIERS Final Report. Washington, DC: Population Council.

Khan, M.E., Sitanshu Sekhar Kar, Vikas Kishor Desai, and Pratibha Patel. "The model works! Repositioning of IUD in public health program in India," FRONTIERS Asia and Near East Research Update no. 15. New Delhi: Population Council.

Khan, M.E., Sitanshu Sekhar Kar, Vikas Kishor Desai, Pratibha Patel, and B.P. Itare. "The model works! Interim findings from an OR project on repositioning of IUD in Gujarat," FRONTIERS Asia and Near East Research Update no. 12. New Delhi: Population Council.

Khan, M.E., Sitanshu Sekhar Kar, Vikas Kishor Desai, Pratibha Patel, B.P. Itare, and Sandhya Barge. "Increasing the accessibility, acceptability and use of the IUD in Gujarat, India," FRONTIERS Final Report. Washington, DC: Population Council.

Khan, M.E., Gul Rashida Shaikh, Sharif Mohammed Ismail Hossain, Ali Mohammad Mir, and Ubaidur Rob. “Introduction of emergency contraceptive pills in the public health system of Pakistan: A south-to-south collaboration," FRONTIERS Final Report. Washington, DC: Population Council.

Koenig, Michael A., Shireen J. Jejeebhoy, John C. Cleland, and Bela Ganatra (eds.). Reproductive Health in India: New Evidence. Jaipur: Rawat Publications.

Kumar, Shiv, Chander Shekhar, N.K. Gupta, Malabika Roy, M.E. Khan, Mary Philip Sebastian, Rukma Idnani, Ardash Bhargava, and Vinita Salvi. 2007. "Provision of emergency contraceptive services through paraprofessionals in India," FRONTIERS Final Report. Washington, DC: Population Council. León, Federico, Ricardo Vernon, Antonieta Martin, and Linda Bruce. The Balanced Counseling Strategy: A Toolkit for Family Planning Service Providers - User's Guide. Washington, DC: Population Council.

Lin, Han, Renshan Ge, Guo-Rong Chen, Guo-Xin Hu, Lei Dong, Qing-Quan Lian, Dianne O. Hardy, Chantal M. Sottas, Xiao-Kun $\mathrm{Li}$, and Matthew P. Hardy. "Involvement of testicular growth factors in fetal Leydig cell aggregation after exposure to phthalate in utero," Proceedings of the National Academy of Sciences of the United States of America 105(20): 7218-7222.

"Malaria in pregnancy pilot projects nationally adopted in Kenya and Malawi," FRONTIERS OR Summary no. 77. Washington, DC: Population Council.

Mannan, M.A., Jafar Ahamd Hakim, Syeda Tazneen Waris, Ashraf Ali, AKM Nurul Hakim, Abdul Hannan, Sameena Chowdhury, Saria Tasnim, Saiful Islam, AOM Rezaul Karim, Sharif Mohammed Ismail Hossain, Ubaidur Rob, and M.E. Khan. "Creating the conditions for scaling up the integration of reproductive health services for men in health and family welfare centers in Bangladesh,"
FRONTIERS Final Report. Washington, DC: Population

Council.

Mruk, Dolores D. “New perspectives in non-hormonal male contraception," Trends in Endocrinology and Metabolism 19(2): 57-64.

Mruk, Dolores D. and Chuen-yan Cheng. "Delivering nonhormonal contraceptives to men: Advances and obstacles " Trends in Biotechnology 26(2): 90-99.

Mutahara, Marium ul, Ubaidur Rob, Ismat Ara Hena, Md Mostafizur Rahman, Mohammad Ainul Haque, and Mohammad Ataur Rahman. "Creating a space for men and youth at health and family welfare centers," DBRHCP Research Update no. 4. Dhaka: Population Council. Onorato, Thomas M., Petrice W. Brown, and Patricia L Morris. "Mono-(2-ethylhexyl) phthalate increase spermatocyte mitochondrial peroxiredoxin 3 and cyclooxygenase 2," Journal of Andrology 29(3): 293-303. "Operations research for managers of reproductive health programs," FRONTIERS CD-ROM. Washington, DC: Population Council.

PAIMAN News Roundup no. 2. Islamabad: Population Council. Pakistan Initiative for Mothers and Newborns (PAIMAN). “Assessment of knowledge and attitudes of married women on maternal and newborn health (MNH) in selected union councils of project districts." Islamabad: Population Council.

- "Assessing routine health information system in selected PAIMAN districts by using lot quality assurance sampling (LQAS) technique." Islamabad: Population Council.

Population Council, The Consultation of Investment in Health Promotion (CIHP), and Reproductive Health Projects. "Final evaluation report on the pilot introduction of youth friendly reproductive health services in Hanoi, Ho Chi Minh City, and An Giang." Hanoi: Pathfinder.

"Programme d'orientation sur la santé des adolescents destiné aux prestataires de soins de santé," CD-ROM. Dakar: Ministère de la Santé et de la Prévention.

“Promoting postpartum contraception among young low parity women in India," FRONTIERS Asia and Near East Regional OR Summary no. 24. New Delhi: Population Council. Quiterio, Gisela, Maritza Molina, Marija Miric, Ricardo Vernon, and M. Estela Rivero-Fuentes. "Situation analysis of the integration of family planning services in postpartum, postabortion and prevention of mother to child transmission programs in the Dominican Republic," FRONTIERS Final Report. Washington, DC: Population Council.

Rahman, Md. Moshiur, Ubaidur Rob, and Tasnima Kibria "Voucher scheme for poor, rural women to utilize pregnancy care," DBRHCP Research Update no. 3. Dhaka: Population Council.

RamaRao, Saumya, Emma Ottolenghi, Nafissatou J. Diop Youmané Faye, Fatou N. Diouf, El H. O. Faye, and Thierno Dieng. 2007. "Evaluation de l'Extension des services de soins après avortement au Sénégal." Dakar: Ministère de la Santé et de la Prévention Médicale, Division de la Santé de la Reproduction.

RamaRao, Saumya, Régine Sitruk-Ware, and John W.

Townsend. "New vistas in contraceptive technology," Gender and Development 16(2): 327-344.

"Réponse d'un pays à la lutte contre l'excision," FRONTIERES Résumés de Recherche Opérationnelle. Dakar: Population Council.

Rivero-Fuentes, M. Estela and Antonieta Martin. "Regional workshop to use the findings from operations research to increase the access, quality and integration of contraceptive services in Latin America and the Caribbean," FRONTIERS Final Report. Washington, DC: Population Council. (Also available in Spanish)

Rivero-Fuentes, M. Estela, Ricardo Vernon, Michaelle Boulos, and Louis-Marie Boulos. "Situation analysis of the integratio of family planning services in postpartum, postabortion and prevention of mother to child transmission programs in Haiti, FRONTIERS Final Report. Washington, DC: Population Council.

Rob, Ubaidur and Md. Noorunnabi Talukder (eds.). 2007. Health Sector Reform: Lessons From Developing Countries. Dhaka: Utso Prokashan.

Santhya, K.G. “Treatment-seeking for reproductive illness in rural Tamil Nadu," in Michael A. Koenig, Shireen J. Jejeebhoy, John C. Cleland, and Bela Ganatra (eds.), Reproductive Health in India: New Evidence. Jaipur: Rawat Publications, pp. 252-265.

Santhya, K.G., Shireen J. Jejeebhoy, and Saswata Ghosh. "Early marriage and sexual and reproductive health risks: Experiences of young women and men in Andhra Pradesh and Madhya Pradesh, India." New Delhi: Population Council. "Senegal: Education and public declarations contribute to Tostan's success," FRONTIERS OR Summary no. 70.

Washington, DC: Population Council.
“Sénégal: L'éducation à base communautaire et les Déclarations Publiques ont contribué à l'Abandon de I'Excision," FRONTIERES Résumés de Recherche Opérationnelle no. 54. Dakar: Population Council, 2007. "Sexual and gender based violence in Africa: Key issues for programming." Nairobi: Population Council.

"Sexual and gender based violence in Africa: Literature review." Nairobi: Population Council.

Sinha, Dipa. "Empowering communities to make pregnancy safer: An intervention in rural Andhra Pradesh," Health and Population Innovation Fellowship Programme Working Paper no. 5. New Delhi: Population Council.

Sloan, Nancy L., Salahuddin Ahmed, Satindra N. Mitra, Nuzhat Choudhury, Mushtaque Chowdhury, Ubaidur Rob, and Beverly Winikoff. "Community-based kangaroo mother care to prevent neonatal and infant mortality: A randomized, controlled cluster trial," Pediatrics 121(5): 1047-1059.

Solis, Freddy, Ana del Carmen Rojas, Adilia Gadea, M. Estela Rivero-Fuentes, and Ricardo Vernon. "Situation analysis of the integration of family planning services in postpartum, postabortion and prevention of mother to child transmission programs in Nicaragua," FRONTIERS Final Report.

Washington, DC: Population Council.

"South Africa: Integrated approach improves quality of postrape care," FRONTIERS OR Summary no. 69. Washington, DC Population Council.

Talukder, Md. Noorunnabi, Repon Chandra Paul, Ubaidur Rob, and Md. Mafizur Rahman. "Improving the quality of FP and RTI services for urban slum population," DBRHCP Research Update no. 1. Dhaka: Population Council.

"Towards a healthy future," training manual. New Delhi: Population Council, 2007.

Van Dijk, M.G., Diana Lara, and Sandra G. García. 2007. “Opinions of decision-makers on the liberalization of abortion laws in Mexico," Salud Pública de México 49(6): 394-400. Varkey, Leila Caleb, Anurag Mishra, and M.E. Khan. “Creating the conditions for scale-up of the Men in Maternity intervention in India," FRONTIERS Final Report. Washington, DC: Population Council.

Vernon, Ricardo. “Increasing women's use of the IUD for family planning," FRONTIERS Program Brief no. 9. Washington, DC: Population Council.

"Meeting the family planning needs of postpartum women," FRONTIERS Program Brief no. 10. Washington, DC Population Council.

Vernon, Ricardo and M. Estela Rivero-Fuentes. “Assessing the need and opportunities for improved linkages between conditional cash transfers and reproductive health programs in Latin America and the Caribbean," FRONTIERS Final Report. Washington, DC: Population Council.

Vernon, Ricardo, Jorge Solórzano, and Blanca Muñoz. 2007. "Introducing sustainable vasectomy services in Guatemala, International Family Planning Perspectives 33(4): 182-187.

"Willingness to pay for reproductive health programs," FRONTIERS CD-ROM. Washington, DC: Population Council, 2007. $\mathrm{Xu}$, Qin, Noriyuki Ohara, Jin Liu, Mariko Amano, Régine SitrukWare, Shigeki Yoshida, and Takeshi Maruo. “Progesterone receptor modulator CDB-2914 induces extracellular matrix metalloproteinase inducer in cultured human uterine leiomyoma cells," Molecular Human Reproduction 14(3): 181-191.

Yam, Eileen A., Georgiana Gordon-Strachan, Garth McIntyre, Horace Fletcher, Sandra G. García, Davida Becker, and Enrique Ezcurra. 2007. "Jamaican and Barbadian health care providers' knowledge, attitudes and practices regarding emergency contraceptive pills," International Family Planning Perspectives 33(4): 160-167.

\section{OTHER PUBLICATIONS}

McNicoll, Geoffrey. 2007. "Review of Michel Foucault, Security, Territory, Population: Lectures at the Collège de France, 1977-78: translated by Graham Burchell," Population and Development Review 33(4): 829-831. Population Council Annual Report, 2007. Population and Development Review34(2).

Prskawetz, Alexia, David E. Bloom, and Wolfgang Lutz (eds.). Population Aging, Human Capital Accumulation, and Productivity Growth, supplement to Population and Development Review, vol. 34. New York: Population Council. "Research that makes a difference: Selected resources," CD ROM. New York: Population Council. (updated June 2008) Studies in Family Planning 39(2). 


\section{Pakistani Girls' Teachers More Likely to Be Absent}

Wh While teaching and learning can take place in schools without desks, books, and other amenities, they cannot take place without a teacher. The impact of teacher absences has been the focus of recent studies in several countries, including Bangladesh, Ecuador, India, Indonesia, Peru, and Uganda.

Population Council researchers made use of a unique longitudinal dataset from rural Pakistan to investigate teacher absences there. They found that gender inequities among students may be exacerbated by teacher absences.

Population Council Bernard Berelson Fellow Sharon Ghuman and Council economist Cynthia B. Lloyd based their analysis on two waves of panel data. These data were collected in rural Punjab and North West Frontier Province (NWFP) in December 1997 and January 2004. These provinces were chosen because they each contain enormous demographic diversity. Twelve rural communities were selected from six districts, three from each province. The communities cover the range of schooling conditions prevalent in NWFP and Punjab. In 1997 data were collected from all public and private schools in each community, as well as any school outside the community attended by at least two community children. The follow-up survey in 2004 revisited all these schools, as well as any new schools inside or outside the communities being attended by community children.

In Pakistan-as in many other Muslim countries, including Afghanistan, Bahrain, Iran, Jordan, Kuwait, Libya, Oman, Qatar, Saudi Arabia, and the United Arab Emirates_- public schools are single-sex and, further, men teach boys and women teach girls at separate institutions. Thus, if female teachers are more likely to miss work than male teachers, the burden of these absences would fall more heavily on girls than boys. In coeducational settings, teacher absences are unlikely to have different implications for girls and boys. (Private schools in Pakistan are generally coeducational.)

\section{What factors influence teacher absence?}

In 1997, about 35 percent of teachers in public girls' schools and 22 percent of teachers in public boys' schools were absent during the researchers' unannounced visits. As a result, about 25 percent of enrolled girls and 17 percent of enrolled boys did not have a teacher present to teach their class. In 2004, absence rates among teachers in public girls' schools had declined to 18 percent, about half the level seen in 1997. But they remained higher than those in public boys' schools (10 percent). "In the two surveys, teacher absence in public girls' schools is about 1.6 to 1.7 times higher than in public boys' schools," said Ghuman. "By contrast, there was essentially no gender gap in the percent of students experiencing teacher absence in coeducational private schools."

The researchers found that among the factors most strongly associated with lower female teacher absence in public schools is better school infrastructure. Conditions in Pakistan's girls' schools have improved since the mid-1990s as the result of government investments in basic amenities. In 1997, for example, none of the public girls' schools the researchers visited had electricity, toilets, and desks, and only 4.5 percent of the public boys' schools had these amenities. By 2004, 26 percent of girls' schools and 21 percent of boys' schools had these amenities. This indicates substantial improvements, particularly for the girls' schools. By contrast, in 1997 and 2004, 83 and 92 percent of private schools, respectively, had all of these amenities.

Another strong predictor of female teacher absence was living outside of the community in which they teach. "Whether they teach in government or private schools, women who live in the same community as the school are substantially less likely to be absent," explained Lloyd.

The design and evaluation of programs that address the lack of teachers and their frequent absence from the classroom are needed. "In India, student achievement was increased substantially by placing additional para-teachers from the community into schools," said Ghuman. "This approach may be worth trying in Pakistan." The construction of middle and high schools for girls, which will increase the supply of secondary school graduates eligible to become teachers, will ease teacher shortages, although this will take time.

\begin{abstract}
SOURCE
Ghuman, Sharon and Cynthia B. Lloyd. 2007. "Teacher absence as a factor in gender inequalities in access to primary schooling in rural Pakistan," Poverty, Gender, and Youth Working Paper no. 1. New York: Population Council.
\end{abstract}

\section{OUTSIDE FUNDING}

The Spencer Foundation, the United Kingdom Department for International Development, and the William and Flora Hewlett Foundation 